\title{
PROBLEM HUKUM REGULASI LMK \& LMKN SEBAGAI PELAKSANAAN UNDANG-UNDANG HAK CIPTA 2014
}

\author{
Agus Sardjono* \\ * Guru Besar Ilmu Hukum Fakultas hukum Universitas Indonesia \\ Korespondensi: agussardjono@yahoo.com \\ Naskah dikirim: 18 Februari 2016 \\ Naskah diterima untuk diterbitkan: 12 Maret 2016
}

\begin{abstract}
UUHC 2014 has been effective since October 2014. The various clauses in the law still contains potential problems, especially those related to copyright in the music, because of its multiple interpretations. The multiple interpretations conditions especially with respect to the setting of the Collective Management Organization. Regulation of the Minister of Law and Human Rights No. 29 In 2014 it adds to the potential problems due to a few mistakes LMKN arrangements concerning the formation and powers rest upon to him. The problem was quite pronounced, since an doctrinal analysis. This paper attempts to reveal the problems in question.
\end{abstract}

Keywords: UUHC, multi-interpretation, permenkumham, and LMKn

\begin{abstract}
Abstrak
UUHC 2014 sudah berlaku sejak bulan Oktober 2014. Berbagai pasal dalam UU tersebut masih mengandung potensi masalah, terutama yang berkaitan dengan hak cipta atas music, karena sifatnya yang multi tafsir. Kondisi multi tafsir tersebut terutama berkenaan dengan pengaturan tentang Lembaga Manajemen Kolektif. Peraturan Menteri Hukum dan HAM No. 29 Tahun 2014 justru menambah potensi masalah karena adanya beberapa kekeliruan pengaturan menyangkut pembentukan LMKN dan kewenangan yang diembankan kepadanya. Masalah itu cukup terasa, terutama bila dilakukan analisis doctrinal. Tulisan ini mencoba mengungkapkan berbagai masalah yang dimaksud.
\end{abstract}

Kata kunci: UUHC, multi-tafsir, permenkumham, dan LMKn

\section{Pendahuluan}

Terbitnya Undang-undang No. 28 Tahun 2014 tentang Hak Cipta (selanjutnya akan disingkat dengan UUHC 2014) menjadi harapan baru bagi insan musik, khususnya para Pencipta, Artis Penyanyi dan Pemusik. Apalagi di 
dalam UU tersebut diatur secara lebih rinci mengenai organisasi LMK (Lembaga Manajemen Kolektif) yang menangani penghimpunan (collecting) dan distribusi royalti. ${ }^{1}$ Setidak-tidaknya tentang bentuk hukum dan apa yang menjadi fungsi dan tugas organisasi tersebut telah mendapatkan pengaturan yang lebih jelas dan rinci.

Namun bila dicermati lebih lanjut, ternyata pengaturan mengenai LMK dan $\mathrm{LMKn}^{2}$ masih mengandung banyak kelemahan, terutama karena mengandung potensi multitafsir dalam pelaksanaannya. Ketentuan tentang LMK dan LMKn di dalam UUHC 2014 sangat membuka peluang untuk ditafsirkan secara berbeda-beda. Tulisan ini mencoba mengungkapkan problematika pengaturan LMK \& LMKn di dalam UUHC 2014, terutama terkait dengan regulasi oleh Menterisebagai wujud pelaksanaan UUHC 2014, yang juga mengandung substansi tafsir eksekutif terhadap UUHC itu sendiri. Pengungkapan ini tidak dimaksud untuk mendegradasi UUHC 2014 maupun menurunkan optimisme para insan musik, melainkan sebagai bekal pemahaman bahwa peluang terjadinya multitafsir akan sangat besar dalam implementasi UU yang dimaksud.

Beberapa pertanyaan mendasar perlu dikemukakan sebagai arah pembahasan dalam tulisan ini, yaitu:

a. Apakah sejatinya bentuk hukum LMKn yang dikehendaki pembentuk undang-undang? Pertanyaan ini perlu diajukan mengingat UUHC 2014 tidak secara tegas menyebutkan bentuk hukum LMKn.

b. Apakah LMKn itu lembaga publik yang memiliki otoritas publik, atau lembaga swasta yang mempunyai kewenangan mengatur berdasarkan kesepakatan antar subjek-subjek hukum perdata?

c. Ketika Menteri Hukum dan HAM membuat regulasi yang menyatakan bahwa LMKn memberikan delegasi kepada LMK untuk memungut royalti kepada pengguna, apa yang menjadi alas hak dari pendelegasian tersebut?

d. Bagaimana seharusnya pembentukan LMKn dilakukan dan apakah yang menjadi wewenang dari LMKn tersebut?

e. Ketika pada kenyataannya LMKn sudah terbentuk atas dasar kekuatan regulasi dari Menteri Hukum dan HAM, bagaimana sikap terbaik yang harus diwujudkan dalam memperbaiki kondisi faktual sehingga pembentukan LMKn tersebut membawa manfaat bagi para pelaku musik?

\footnotetext{
${ }^{1}$ Lembaga Manajemen Kolektif adalah institusi yang berbentuk badan hukum nirlaba yang diberi kuasa dari pencipta, pemegang hak cipta, dan/atau pemilik hak terkait guna mengelola hak ekonominya dalam bentuk menghimpun dan mendistribusikan royalty. [Pasal 1 butir (22) UUHC 2014].

${ }^{2}$ LMKn merupakan singkatan dari Lembaga Manajemen Kolektif nasional. Lihat Pasal 89 ayat (1) UUHC. Perlu dicatat bahwa UUHC 2014 menggunakan huruf " $n$ " kecil tentu mengandung makna tertentu bahwa "nasional" yang dimaksud merupakan kata keterangan, bukan bagian dari nama, ketika ia ditulis dengan huruf "N" kapital, seperti BPN (Badan Pertanahan Nasional).
} 
Pertanyaan-pertanyaan tersebut di atas perlu mendapatkan jawaban yang secara doctrinal dapat dipertanggungjawabkan agar dalam pelaksanaannya kemudian tidak menimbulkan masalah dan secara ideal membawa manfaat bagi masyarakat, terutama bagi pelaku musik.

\section{Pengaturan Yang Mengundang Masalah}

Pasal 89 ayat (1) menyebutkan bahwa "untuk mengelola royalti hak cipta bidang lagu dan/atau musik dibentuk 2 (dua) LMKn (dengan "n" huruf kecil = nasional) yang masing-masing merepresentasikan keterwakilan kepentingan pencipta dan kepentingan pemilik hak terkait". Teks pasal tesebut menggunakan kata "nasional" dengan " $n$ " huruf kecil. Apakah kemudian dapat ditafsirkan secara sepihak bahwa " $n$ " kecil itu kemudian ditulis dengan huruf besar atau kapital menjadi LMKN? Jawaban atas pertanyaan ini kemudian akan berimplikasi kepada pembahasan masalah pertama, apakah bentuk hukum LMKN menurut UUHC 2014?

Selain persoalan tersebut, bunyi kalimat di dalam pasal 89 ayat (1) UUHC 2014 itu dapat ditafsirkan bahwa nantinya di Indonesia "hanya ada dua" organisasi bernama LMKn, yaitu LMKn pencipta, dan LMKn pemilik hak terkait. Namun tidak salah juga untuk menafsirkan bahwa di Indonesia nantinya akan "ada dua jenis" LMKn, yaitu LMKn pencipta, dan LMKn pemilik hak terkait. Mana dari kedua penafsiran tersebut yang lebih tepat bergantung pada ketentuan-ketentuan lainnya tentang LMK dan LMKn. Pembentuk UU itu sendiri (legislative), apalagi drafternya, bahkan tidak lagi mempunyai otoritas untuk menafsirkan sesuai dengan kehendak semula, karena yang akan menafsirkan kemudian adalah eksekutif yang bertugas melaksanakannya (implementation of the law), dan yudikatif yang bertugas menegakkan aturan hukumnya (enforcement of the law). Kedua lembaga ini boleh jadi akan memiliki tafsir yang berbeda. Dengan demikian peran Pemerintah dan Pengadilan menjadi sangat sentral dalam urusan ini.

Beberapa pengaturan yang mempengaruhi penafsiran terhadap eksistensi LMKN adalah sebagai berikut:

1. Pasal 1 butir (22) tentang definisi LMK dan Pasal 87 ayat (1\& 2) UUHC 2014 mengandung makna bahwa yang dapat menghimpun royalty dari para pengguna (users) adalah LMK (tanpa $\mathrm{N}$ huruf kapital). Dengan demikian, untuk memberikan kewenangan kepada LMK nasional memungut royalti dari pengguna harus terlebih dahulu dinyatakan di dalam UUHC bahwa LMK nasional adalah organisasi yang dibentuk oleh LMK-LMK yang bergabung ke dalam LMK nasional dalam rangka menyederhanakan proses pemungutan royalti secara bersama-sama dari para pengguna (users). Mengingat basis kewenangan LMK dalam memungut royalti dari para pengguna adalah adanya surat kuasa dari para pencipta dan/atau para pemilik hak terkait, makadengan demikian, harus ada kuasa substitusi terlebih dahulu dari LMK kepada LMK 
nasional, sehingga LMK nasional mempunyai kewenangan mewakili para pencipta dan pemilik hak terkait melalui masingmasing LMK.

Tampaknya di dalam UUHC tidak ada penegasan bahwa LMKn dibentuk oleh LMK-LMK. Ketentuan yang ada hanya menegaskan bahwa untuk pengelolaan royalti hak cipta bidang lagu dan/atau musik dibentuk 2 (dua) Lembaga Manajemen Kolektif nasional (LMKn) yang masing-masing merepresentasikan kepentingan pencipta dan pemilik hak terkait ${ }^{3}$. Sedangkan pemilik hak terkait itu sendiri terdiri atas 3 (tiga) pihak, yaitu: (1) pelaku/artis, (2) produser, dan (3) lembaga penyiaran. Dengan demikian, pembentukan LMK nasional Hak Cipta dan LMK nasional Hak Terkait menurut UUHC 2014 harus dilakukan oleh masing-masing LMK yang bersepakat untuk bergabung ke dalam LMK nasional.

Konsekuensi hukum dari tafsir tersebut adalah dimungkinkannya pembentukan LMK nasional yang akan mewakili LMK-LMK sejenis yang bersepakat untuk bergabung. Dengan demikian tidak ada LMK nasional yang bersifat tunggal di dalam wilayah Negara Indonesia. Ketentuan ini sejalan dengan sistem Konstitusi (UUD'45) bahwa warga Negara mempunyai kebebasan untuk berserikat dan berkumpul. Artinya tidak ada ketentuan UU yang dapat memaksa LMK untuk bergabung hanya ke dalam LMK nasional yang bersifat tunggal di wilayah Indonesia.

UUHC 2014 sejalan dengan prinsip kebebasan berserikat dan berkumpul yang dianut di dalam sistem ketatanegaaan Republik Indonesia karena di dalam UUHC tidak ditegaskan bahwa LMKLMK "harus" atau "wajib" bergabung ke dalam LMK nasional. Hal ini sudah benar, karena jika di dalam UUHC 2014 diatur tentang keharusan adanya LMKN yang bersifat tunggal, maka ketentuan ini bertentangan dengan UUD yang berpeluang besar untuk digugat ke Mahkamah Konstitusi.

Tafsir ini tidak memberi peluang kepada Pemerintah untuk membentuk LMKN ("N" dengan huruf kapital) dan kemudian "memaksa" LMK-LMK untuk bergabung ke dalamnya. Peluang yang ada hanyalah memberikan fasilitas kepada LMK-LMK untuk berinisiasi membentuk LMK nasional. Itupun tetap tidak dapat mengarahkan untuk hanya membentuk LMKN tunggal di wilayah Negara Republik Indonesia. Pembentukan LMKN tunggal hanya dapat dilakukan atas dasar kehendak bebas dari LMK-LMK yang sudah ada. Paling jauh Pemerintah menganjurkan pembentukan

${ }^{3}$ Lihat kembali Pasal 89 ayat (1) UUHC 2014. Perlu dicatat bahwa pemilik hak terkait itu terdiri dari 3 pihak, yaitu: (1) pelaku/performers, (2) produser, dan (3) lembaga penyiaran. Dengan demikian yang berhak membentuk LMK itu bukan hanya artis dan produser, melainkan juga termasuk Lembaga Penyiaran. 
LMKN tunggal, semata-mata dalam rangka membantu mempermudah pemungutan royalti dari para pengguna musik.

2. Ketentuan Pasal 89 UUHC yang menyinggung tentang LMK nasional menegaskan bahwa ada 2 jenis LMKn, yaitu: (a) LMKn yang mengemban kepentingan pencipta, dan (b) LKMn yang mengemban kepentingan pemiliki hak terkait. UUHC 2014 dan WPPT $^{4}$ mengatur bahwa ada 2 pihak yang menjadi "pemilik hak terkait", yaitu: pelaku (performers) dan produser. ${ }^{5}$ Dengan demikian, dimungkinkan untuk adanya 2 jenis LMKn pengemban kepentingan pemilik hak terkait, yaitu LMKn yang mengemban kepentingan para pelaku (artis penyanyi dan pemusik), (selanjutnya disingkat LMKn Pelaku/Artis) dan LMKn yang mengemban kepentingan para produser (selanjutnya disingkat LMKn Produser). ${ }^{6}$ Tafsir ini dipertegas bahwa di dalam UUHC 2014 tidak ada pengaturan yang "mewajibkan" para pelaku(performers) untuk bergabung dengan produser untuk hanya membentuk wadah tunggal (LMKn). Dalam hal ini UUHC 2014 sudah selaras dengan UUD '45 yang menjamin kebebasan warga Negara untuk berserikat dan berkumpul. Justru jika di dalam UUHC 2014 ada ketentuan yang mewajibkan para pelaku untuk hanya bergabung dengan produser dalam wadah tunggal LMKn, hal itu bertentangan dengan UUD ' 45 yang berpeluang besar untuk digugat ke Mahkamah Konstitusi. Selain daripada itu, tidak semua artis tergabung ke dalam produser karya rekaman (phonograms) tertentu, sehingga mereka tetap mendapatkan kesempatan untuk bergabung dengan LMK yang tidak bergabung ke dalam wadah tunggal LMKn Hak Terkait, melainkan bersama-sama dengan LMK Artis lainnya membentuk LMKn Pelaku. Sekadar contoh, bahwa dengan perkembangan jaman dan teknologi, saat ini banyak muncul produser-produser musik Indie yang tidak bergabung ke dalam asosiasi industri rekaman. ${ }^{7}$ Kepada mereka UU harus memberi kesempatan untuk mendapatkan

\footnotetext{
${ }^{4}$ WPPT adalah singkatan dari WIPO Performances and Phonograms Treaty (adopted in Geneva on December 20, 1996)

5 WPPT merupakan konvensi tentang performance dan phonogram, sehingga di dalamnya memang tidak mengatur mengenai salah satu hak terkait lainnya, yaitu broadcasting rights.

${ }^{6}$ Lembaga penyiaran sebagai salah satu pemegang hak terkait seharusnya juga mempunyai hak yang sama dalam persoalan LMK ini, yaitu untuk membentuk LMK yang akan mengelola hak ekonomi atas karya siarannya. Oleh karenanya LMKN Hak Siar juga menjadi sesuatu yang niscaya. Namun tulisan ini belum mengungkapkan persoalan menyangkut hak siar ini. Pada waktu dan kesempatan yang lain mudah-mudahan persoalan hak siar ini akan dibahas lebih lanjut.

7 Ada beberapa nama Indie Label di Indonesia yang dapat ditelusuri dalam situs: <https://widalcommunity.wordpress.com/artikel/daftar-nama-label-rekaman-indie/>. Beberapa di antaranya: Staria Music Indonesia, Variant Music Indonesia, Metal Grounds Records, Rottrevore Record, THT Production, dan lain-lain. Data tersebut diakses dari situs tersebut pada hari Selasa, 8 Maret 2016, pukul 15.00 wib.
} 
perlindungan hukum terkait dengan pengelolaan hak ekonominya. Dalam contoh nyata yang ada di Indonesia, saat ini sudah ada LMK yang hanya beranggotakan artis penyanyi dan pemusik, yaitu LMK PAPPRI (Persatuan Artis Penyanyi, Pencipta Lagu, dan Pemusik Republik Indonesia).

3. Pasal 88 UUHC 2014 dan Permenkumham No. 29/2014 mengatur mengenai perijinan LMK (bukan LMKN). Untuk mendapatkan ijin diperlukan persyaratan sebagaimana disebutkan di dalam ayat (2) pasal 88 tersebut, yaitu:

a. Berbentuk badan hukum nirlaba;

b. Mendapat kuasa dari pencipta, atau pemegang hak cipta, atau pemegang hak terkait, baik performers maupun produser;

c. "Memiliki" - [sic] atau mendapatkan kuasa minimal dari 200 orang pencipta untuk LMK Pencipta, atau minimal 50 orang pelaku/artis untuk LMK Pelaku/Artis, atau 50 orang produser untuk LMK Produser;

d. Bertujuan menghimpun dan mendistribusikan royalti; dan

e. Mampu (memiliki kemampuan) untuk menghimpun dan mendistribusikan royalti

Ketentuan tentang persyaratan tersebut kemudian dijabarkan lagi dalam Permenkumhan tersebut di atas, yaitu dengan penambahan syarat untuk pemberian ijin operasional sbb:

a. Salinan Akta Pendirian;

b. Salinan Keputusan Menteri mengenai pengesahan badan hukum;

c. Surat Kuasa dari pencipta, atau pelaku, atau produser;

d. KTP Pengurus LMK;

e. Daftar nama anggota LMK (baca: mestinya daftar nama pemberi kuasa);

f. Daftar karya cipta dan atau produk hak terkait;

g. Surat pernyataan mampu menghimpun dan mendistribusikan royalti.

Bila semua persyaratan di atas terpenuhi, maka Menteri "harus" memberi ijin operasional dalam jangka waktu 14 (empatbelas) hari kerja sejak tanggal permohonan diterima secara lengkap.

Permasalahan hukumnya adalah, justru UUHC tidak mengatur mengenai persyaratan LMK nasional. Bahkan Permenkumhan No. 29/2014 juga tidak mengatur mengenai perijinan LMKn. Hal ini dapat ditafsirkan bahwa ketentuan tentang LMK berlaku secara mutatis mutandis terhadap LMK nasional.Apalagi di dalam Permenkumham ini dengan tegas disebutkan dalam Pasal 1 butir (7) bahwa LMK nasional adalah LMK. Penegasan ini sejalan dengan UUHC 2014 yang tidak pernah mendefinisikan LMKN secara 
tersendiri. Secara singkat dapat disimpulkan bahwa bahwa LMKN adalah LMK juga. Artinya, LMK nasional juga harus (a) berbentuk badan hukum nirlaba; (b) mendapat kuasa dari pencipta, atau pemegang hak cipta, atau pemegang hak terkait, baik performers maupun produser; (c) "memiliki" - [sic] atau mendapatkan kuasa minimal dari 200 orang pencipta untuk LMK Pencipta, atau minimal 50 orang pelaku untuk LMK Artis, atau 50 orang produser untuk LMK Produser; (d) bertujuan menghimpun dan mendistribusikan royalti; dan (e) mampu (memiliki kemampuan) untuk menghimpun dan mendistribusikan royalti. ${ }^{8}$

Jika tafsir ini benar, maka LMK nasional akan menjadi semacam hasil konsolidasi badan hukum LMK-LMK, karena semua pemberi kuasa LMK kemudian masuk menjadi pemberi kuasa LMK nasional. LMK nasional harus menjadi semacam Federasi dari LMK-LMK. Bilamana tafsir ini diterima, maka persyaratan LMK nasional harus diatur secara berbeda dengan LMK, yaitu dengan menambahkan bahwa keanggotaan LMK nasional terdiri dari LMKLMK yang memberikan kuasa substitusi kepada LMK nasional yang dibentuk atas dasar kesepakatan dari LMK-LMK yang sudah mendapatkan ijin operasional dari Menteri. Pada kenyataannya ketentuan semacam ini belum diatur secara demikian di dalam UUHC 2014.

4. Pasal 87 ayat (2) UUHC 2014 menegaskan bahwa "pengguna (users) ... membayar royalti kepada pencipta, pemegang hak cipta, atau pemilik hak terkait, melalui LMK'. Hal ini selaras dengan Pasal 1 butir (22) yang menegaskan bahwa LMK adalah lembaga yang mengelola hak ekonomi pencipta, pemegang hak cipta, atau pemilik hak terkait dalam bentuk menghimpun dan mendistribusikan royalti.

Ketentuan ini dengan jelas menetapkan bahwa yang mempunyai wewenang menghimpun dan mendistribusikan royaltiadalah LMK.Artinya, semua LMK yang telah mendapatkan ijin operasional berwenang menghimpun dan mendistribusikan royalti. Pada waktu yang sama, di dalam Pasal 89 ayat (2) UUHC 2014 terdapat ketentuan yang memberi wewenang juga kepada LMK nasional untuk menghimpun dan mendistribusikan royalti. Dengan demikian, baik LMK maupun LMKn, kedua-duanya oleh UUHC diberikan kewenangan untuk memungut royalti dari pengguna. Jika tafsir ini benar, maka tujuan menyederhanakan proses pemungutan royalti kepada pengguna menjadi tidak tercapai. Situasi ini memiliki potensi konflik yang cukup besar. LMK-LMK yang merasa hakhaknya tidak terakomodasi dalam LMKn tetap dapat memungut

${ }^{8}$ Lihat kembali Pasal 88 ayat (2) UUHC 2014. 
royalti sendiri kepada pengguna. Hal ini tentu akan memusingkan pengguna, yang pada gilirannya tidak menciptakan suasana yang kondusif dalam pengembangan industri musik. Satu-satunya jalan untuk mencegah LMK yang enggan bergabung dengan LMKnadalah dengan mencabut ijin operasional LMK yang bersangkutan. Satu-satunya alasan yang sah untuk mencabut ijin operasional adalah tidak terpenuhinya syarat-syarat yang ditentukan UUHC. Namun Jika LMK yang bersangkutantelah memenuhi semua syarat yang ditentukan Pasal 88 ayat (2) UUHC, maka pencabutan ijin itu menjadi sebuah bentuk kesewenang-wenangan Pemerintah yang sangat rentan untuk digugat melalui Pengadilan Tata Usaha Negara (PTUN).

Solusi yang paling masuk akal adalah bahwa LMKn harus menjadi pemegang kuasa substitusi dari semua LMK yang bergabung, dengan ketentuan bahwa di dalam perjanjian pemberian kuasa yang dimaksud terdapat klausula bahwa LMK yang telah memberikan kuasa substitusi kepada LMKn tidak berwenang lagi mengatasnamakan pencipta atau pemegang hak cipta atau pemilik hak terkait memungut royalti langsung kepada pengguna. Dengan cara demikian, LMKn menurut hukum mendapat mandat dari LMK-LMK untuk memungut royalti kepada pengguna. Apabila LMKn tersebut tidak mempunyai mandat atau mendapatkan kuasa substitusi dari LMK-LMK, maka sejatinya LMKn tersebut tidak memiliki legal standing untuk mewakili pencipta atau artis/performers, atau produser.

Melalui paparan ringkas tersebut di atas menjadi jelas bahwa tafsir yang konsisten terhadap Pasal 89 ayat (1) UUHC adalah bahwa di Indonesia nantinya akan ada dua jenis LMKn (bukan "hanya dua" LMKN), yaitu LMKn Pencipta dan LMKn Hak Terkait. Sedangkan LMKn Hak Terkait juga ada dua jenis, yaitu: LMKn Pelaku, dan LMKn Produser. Sebenarnya boleh saja ada LMKn Lembaga Penyiaran, karena salah satu substansi Hak Terkait menurut UUHC adalah Hak Siar itu.Namun demikian, jika ada pihak yang menafsirkan bahwa LMKn itu hanya ada dua, maka meskipun tafsirnya menjadi tidak konsisten, tetapi UUHC memang membuka peluang untuk adanya tafsir tersebut. Dengan demikian dapat disimpulkan bahwa UUHC masih banyak mengandung kelemahan, khususnya yang berkenaan dengan LMK dan LMKn, karena berpotensi menimbulkan masalah baru. Untuk itu agar persoalan LMK dan LMKn tidak berujung pada konflik karena sifat pengaturannya yang multitafsir, maka ada baiknya dilakukan revisi UUHC, atau paling kurang membuat aturan pelaksanaan berbentuk Peraturan Pemerintah "yang baik", yang proses penyusunannya jauh dari kepentingan kelompok tertentu, dan mengajak semua komponen stake holders, meskipun pihak ini tidak sejalan dengan pemikiran drafter Pemerintah. 


\section{Bentuk Hukum LMK Nasional}

Uraian panjang lebar di atas membawa kita pada kemungkinan menjawab permasalahan pertama, yaitu, apakah sesugguhnya bentuk hukum LMK nasional (LMKn)? UUHC hanya menegaskan bahwa LMKn berbentuk badan hukum nirlaba. Dalam sistem hukum yang dikenal di Indonesia atau di duniaterdapat badan hukum bernama Yayasan (berdasarkan UU Yayasan), Perkumpulan (berdasarkan Kitab Undang-undang Hukum Perdata), dan Federasi sebagaimana dikenal di dalam dunia praktis, seperti Federasi Sepak Bola, Federasi Serikat Buruh, dan sebagainya. ${ }^{9}$

Badan Hukum nirlaba untuk LMK hak cipta yang sudah dikenal sebelum UUHC 2014 antara lain, Yayasan Karya Cipta Indonesia (YKCI), Wahana Musik Indonesia (WAMI), dan lain-lainnya. Semua lembaga hukum tersebut di atas dibentuk atas dasar prakarsa subjek hukum perdata atau didirikan oleh pihak swasta, yaitu mereka yang ingin membantu para pencipta dalam mengumpulkan hak-haknya berupa royalti atas penggunaan karya cipta mereka berupa lagu atau music.

UUHC 2014 tidak dengan tegas menyebutkan bentuk hukum LMKn. Akan tetapi mengacu pada kelahiran LMK-LMK hak cipta yang sudah ada, maka berdasarkan uraian panjang lebar di atas, sudah sepatutnya jika LMKn adalah perkumpulan dari LMK-LMK yang sudah mendapatkan ijin operasional dari Menteri Hukum dan HAM berdasarkan ketentuan Pasal 88 ayat (2) UUHC 2016. Sejarah pembentukan LMKn itu sendiri sudah dimulai sejak sebelum diundangkannya UUHC 2014, yaitu melalui pembicaraan beberapa LMK dan Asosiasi Industri Rekaman Indonesia, PAPPRI, dan sebagainya. ${ }^{10}$ Idea

9 Wikipedia memberikan definisi mengenai organisasi nirlaba sebagai berikut: Organisasi nirlaba atau organisasi non profit adalah suatu organisasi yang bersasaran pokok untuk mendukung suatu isu atau perihal di dalam menarik perhatian publik untuk suatu tujuan yang tidak komersil, tanpa ada perhatian terhadap hal-hal yang bersifat mencari laba (moneter). Organisasi nirlaba meliputi gereja, sekolah, derma publik, rumah sakit dan klinik publik, organisasi politis, bantuan masyarakat dalam hal perundang-undangan, organisasi jasa sukarelawan, serikat buruh, asosiasi profesional, institut riset, museum, dan beberapa para petugas pemerintah. Lihat <https://id.wikipedia.org/wiki/Organisasi_nirlaba>, diakses pad hari Selasa, 8 Maret 2016. Definisi ini lebih menekankan pada tujuan organisasinya, yaitu bukan untuk mencari laba (non-profit organization). Sedangkan bentuk hukumnya diatur dalam undang-undang yang berbeda-beda, antara lain Yayasan sebagaimana diatur di dalam UU Yayasan Nomor 16 Tahun 2001, Perkumpulan, sebagaimana diatur di dalam KUHPerdata (Burgerlijk Wetboek - Pasal 1653 s/d 1665). Ciri perkumpulan sebagai badan hukum dapat disimpulkan dari Pasal 1655 yang menegaskan bahwa para pengurusnya dapat melakukan tindakan hukum atas nama perkumpulan itu sendiri. Dengan kata lain, perkumpulan merupakan pengemban hak dan kewajiban. Perkumpulan ini dapat juga menampung gabungan dari beberapa lembaga yang ingin bergabung membentuk federasi, seperti federasi sepak bola internasional, Fédération Internationale de Football Association (FIFA), Union of European Football Associations (UEFA), Confédération Africaine de Football $(C A F)$, federasi serikat buruh, dan sebagainya. Dalam federasi serikat buruh, yang bergabung adalah berbagai serikat buruh yang ada, baik nasional maupun internasional seperti ILO.

${ }^{10}$ Kebetulan penulis terlibat dalam pembicaraan-pembicaraan tersebut. Dengan demkian, data sejarah ini lebih bersifat pengalaman pribadi dari orang yang turut aktif dalam pembicaraan-pembicaraan terkait dengan niat membentuk LMK "satu pintu" yang akan melaksanakan proses penghimpunan dan pendistribusian royalty. Idea membentuk lembaga pelayanan "satu pintu" ini dimaksudkan untuk menyederhanakan proses penghimpunan dan pendistribusian royalty dari pengguna kepada para pemegang hak. 
awalnya adalah untuk menyederhanakan proses penghimpunan royalti dari para pengguna music agar tidak terjadi pemungutan berulang-ulang oleh berbagai LMK yang ada pada waktu itu. Atas dasar latar belakang sejarah itu, maka sangat ideal jika LMKn itu dibentuk oleh LMK-LMK yang ada. Bentuk hukumnya sendiri dapat mengacu pada ketentuan tentang "perkumpulan" sebagaimana diatur di dalam KUHPerdata Pasal 1653 sampai dengan 1665. Tentang penamaannya bisa saja menggunakan "federasi" LMK. Yang terpenting adalah bahwa gagasan menggunakan"satu pintu" dalam proses pemungutan royalti dapat terwujud, tanpa harus menghilangkan eksistensi LMK-LMK yang sudah ada. Contoh federasi yang paling pas untuk LMKn adalah FIFA. Sebagai federasi, FIFA dapat melakukan tindakan hukum sendiri sebagai suatu subjek (badan hukum). Pada ketika yang sama, perserikatan sepak bola yang bergabung ke dalam FIFA masih tetap eksis dan dapat mengurus urusan internalnya masing-masing. Begitupun federasi LMK-LMK yang hendak dibentuk menjadi LMKn. LMKn dapat melakukan pemungutan royalti kepada pihak ketiga (pengguna/user), selanjutnya royalti yang terkumpul dibagikan kepada LMK-LMK anggotanya. Nantinya, LMK-LMK itulah yang akan membagikan royalti kepada para pemegang haknya masingmasing, yaitu pencipta dan pelaku music.

Akan tetapi sebelum pembicaraan pembentukan LMKn mencapai kesepakatan, ternyata UUHC 2014 diberlakukan. Walaupun demikian, sejatinya semangat yang ada dalam proses pembentukan LMKn itu dapat tetap diwujudkan apabila mengacu pada bunyi pasal-pasal yang ada di dalam UUHC 2014. Sayangnya, regulasi yang dikeluarkan oleh Pemerintah c.q. Kementerian Hukum dan HAM mengatur hal-hal yang berbeda dari gagasan semula. LMKN (dengan " $\mathrm{N}$ " huruf kapital) kemudian dibentuk dengan menggunakan bentuk hukum KOMISI yang beranggotakan Komisioner yang dipilih ${ }^{11}$ dan diangkat oleh Menteri Hukum dan HAM. Nama Komisi itu sendiri adalah LMKN yang terdiri dari 10 orang Komisioner. Dengan pembentukan LMKN ini maka bentuk hukum LMKn ("n" huruf kecil) menjadi berbeda dari maksud semula, yaitu badan hukum nirlaba. Bentuk hukum LMKN adalah Komisi bentukan Pemerintah.

Meskipun demikian, kelembagaan LMKN itu sendiri secara hukum belum begitu jelas, apakah LMKN merupakan lembaga privat (private organzation) atau lembaga pemerintah. Ketidakjelasan itu didasarkan pada kenyataan bahwa lembaga itu dibentuk oleh Pemerintah dan dilantik oleh Pemerintah dengan anggota-anggotanya menggunakan nomenklatur Komisioner. Merujuk pada istilah Komisi Pemilihan Umum (KPU), Komisi Pengawas Persaingan Usaha (KPPU), Komisi Pemberantasan Korupsi (KPK), Komisi Yudisial (KY), maka menurut logika atau sekurang-kurangnya asumsi yang ada mengharuskan kita menafsirkan LMKN adalah Komisi negara,

11 Proses pemilihannya dilakukan oleh sebuah Panitya Seleksi yang dibentuk oleh Menteri Hukum dan HAM berdasakan Keputusan Menteri No. M.HH-01.01 Tahun 2014 tentang Penetapan Panitia Seleksi Calon Komisioner Lembaga Manajemen Kolektif Nasional Pencipta dan Lembaga Manajemen Kolektif Nasional Hak Terkait. 
karena anggotanya adalah Komisioner, sebagaimana KPU, KPPU, KPK, KY, dsb. Apakah benar demikian? Orang dapat berdebat tanpa dasar hukum yang jelas.

Sebaliknya, apabila LMKN hendak dikatakan sebagai private organization, kenyataannya lembaga itu tidak dibentuk oleh swasta, melainkan oleh Pemerintah. Mungkinkah kita menggunakan analogi dengan PT BUMN untuk menegaskan bahwa LMKN adalah private organization? Analogi tersebut boleh saja digunakan, namun tetap harus menggunakan dasar logika yang konsisten.

Pembentukan PT BUMN didasarkan pada teorihukum tentang perseroan terbatas sebagai badan hukum, yang dikenal dengan "teori kekayaan bertujuan". ${ }^{12}$ Dalam teori ini dijelaskan bahwa badan hukum sebagai subjek hukum ciptaan undang-undang terbentuk disebabkan karena adanya "kekayaan yang dipisahkan" untuk digunakan dalam mencapai tujuan tertentu. Dalam konteks PT BUMN, kekayaan negara yang dipisahkan dikonversi menjadi saham. PT BUMN itu sendiri tujuannya jelas, yaitu untuk mencari laba sebagaimana nature dari perseroan terbatas, yaitu sebagai salah satu bentuk badan usaha. Ketika BUMN itu sendiri beraktivitas, maka sepenuhnya aktivitasnya itu berada di dalam ranah perdata yaitu menjalan kegiatan usaha bisnis (commercial activities). BUMN tidak memiliki kewenangan membuat peraturan yang bersifat mengikat publik (regulation). Pendirian PT BUMN itu sendiri tetap tunduk pada ketentuan Undang-undang Perseroan Terbatas No. 40 Tahun 2007, dengan seluruh rangkaian yang telah diatur di dalam UU tersebut. Dengan demikian, jika analogi ini hendak diterapkan maka pembentukan LMKN tetap harus dilakukan berdasarkan ketentuan tentang "perkumpulan" sebagaimana diatur di dalam KUHPerdata.

Mencermati uraian di atas, kita masih menemukan kendala hukum untuk menegaskan apakah sebenarnya bentuk hukum LMKN bentukan Pemerintah tersebut? Apakah dia merupakan perkumpulan atau Yayasan? Satu-satunya jawaban rasional yang dapat dikemukakan adalah bahwa LMKN itu bukan badan hukum nirlaba yang dimaksudkan UUHC 2014. LMKN harusnya merupakan LMKn (n huruf kecil) yang dibentuk oleh LMK-LMK dalam rangka menyerdehanakan proses pemungutan royalti dari para pengguna.

\section{Apakah LMKn Mempunyai Kewenangan Mengatur?}

Apabila LMKn adalah lembaga public karena ia dibentuk oleh Pemerintah melalui Keputusan Menteri Hukum dan HAM, ${ }^{13}$ maka boleh jadi

\footnotetext{
12 Beberapa teori yang dikemukakan oleh para sarjana tentang "teori kekayaan bertujuan" antara lain dikemukakan oleh A. Brinz dan Van Der Hayden. Referensi lebih lanjut baca Chidir Ali, Badan Hukum, (Bandung: Alumni, 1987).

${ }^{13}$ Berita tentang pelantikan LMKN oleh Menteri Hukum dan HAM dapat disimak di dalam situs Direktorat Jenderal Kekayaan Intelektual yang dapat diakses di: <http://humas.dgip.go.id/press-releasekeputusan-pansel-pemilihan-komisioner-lmkn-di-bidang-lagu-danatau-musik/>, diakses pada tanggal 9 Maret 2016 .
} 
LMKn akan diberi wewenang administrative yang berasal dari delegasi kewenangan yang dimiliki oleh Menteri Hukum dan HAM. Bila demikian halnya, maka LMKn mungkin saja memiliki wewenang sebagai lembaga public atau lembaga administasi negara.

Dari uraian sebelumnya, sulit untuk menerima dalil bahwa LMKn adalah lembaga public. LMKn menurut UUHC 2014 adalah badan hukum nirlaba yang merupakan lembaga perdata. Jika Pemerintah membentuk LMKn sebagai lembaga public, maka lembaga ini berbeda dari apa yang dimaksud UUHC bahwa LMKn adalah lembaga perdata, yang tugas utamanya menerima kuasa dari pemegang hak, melalui LMK, untuk memungut royalti dari para pengguna music. UUHC 2014 perlu menegaskan bahwa LMKn juga berhak memungut royalti karena LMKn adalah LMK juga sebagaimana dimaksud Pasal 87 dan 88 UUHC 2014. LMKn juga harus memenuhi persyaratan sebagaimana diatur di dalam Pasal 88 ayat 2 UUHC, baru kemudian UUHC menegaskan bahwa berdasarkan Pasal 89 ayat (2) LMK tersebut berwenang memungut royalti karena disamping telah mendapatkan kuasa dari para pemegang hak, juga sudah memenuhi syarat dan karenanya mendapatkan ijin dari Pemerintah untuk menjadi organisasi yang tugasnya memungut royalti atas nama pemegang hak.

Lembaga perdata semacam ini (LMKn) tentu saja tidak memiliki otoritas untuk membuat aturan yang bersifat publik (mengikat publik). Dengan demikian, Statuta LMKN yang telah disahkan oleh Menteri Hukum dan HAM dengan SK No. HKI.2.OT.03.01-09 tertanggal 23 Desember 2015 menjadi kurang tepat. ${ }^{14}$ LMKn hanya dapat membuat aturan yang dibuat atas dasar kesepakatan para anggotanya (LMK-LMK) untuk mengatur bagaimana melakukan pemungutan terhadap pihak ketiga dan bagaimana membagi hasil kerjanya memungut royalti tersebut. Merujuk pada pemikiran tentang semiautonomous social field, maka LMKn dapat membuat aturan internal (bukan aturan publik) untuk mengatur bagaimana menentukan tarif royalti, bagaimana melakukan pemungutan royalti, bagaimana mendistribusikan royalti, bagaimana menggunakan rekening bank secara bersama-sama, dan sebagainya. LMKn dapat dianggap sebagai semi-autonomous social field karena ia merupakan sekumpulan orang atau masyarakat (bukan organisasi bentukan Pemerintah), yang mempunyai aturan sendiri tentang hal-hal yang menjadi lingkup hubungan sosialnya di antara para pelaku music (masyarakat musik). Dalam konteks internasional, aturan semacam ini sudah diterapkan oleh berbagai CMO (collecting management organization) di dunia seperti CISAC, JASRAC, dan lain-lain. Organisasi-organisasi semacam ini boleh dikatakan juga sebagai semi-autonomous social field yang memiliki aturan-aturan sendiri. ${ }^{15}$

14 Lihat butir C. Statuta LMKN berkenaan dengan Keanggotaan dan Mekanisme Pertanggungjawaban Lembaga Manajemen Kolektif Nasional (Lampiran SK Menkumham No. HKI.2.OT.03.01-09)

15 Referensi tentang hal ini dapat ditelusuri melalui berbagai buku atau artikel yang membicarakan tentang semi-autonomous social field. Lihat Sally Falk Moore, "Law and Social Change: The Semi-Autonomous Social Fields as an Appropriate Subject of Study", Law and Society Review, Vol.7 
Dengan uraian ringkas diatas dapat disimpulkan bahwa LMKn adalah organisasi swasta yang dapat membuat aturan sendiri atas dasar kesepakatan dan aturan-aturan khusus yang biasanya berlaku di antara sesama anggota masyarakat tertentu. Dalam hal ini adalah masyarakat industri musik. Aturanaturan tersebut bukan aturan-aturan yang ditetapkan oleh Pemerintah melalui LMKN atau aturan-aturan LMKN yang ditetapkan oleh Pemerintah.

\section{Apakah Menteri dapat Membuat Aturan Tentang Delegasi dari LMKN kepada LMK untuk Memungut Royalti?}

UUHC 2014 Pasal 89 ayat (2) jo Pasal 88 ayat (1 \& 2) jo Pasal 87 ayat (1 \& 2), menegaskan bahwa LMK adalah lembaga yang melakukan pemungutan royalti setelah mendapatkan ijin operasional dari Menteri Hukum dan HAM. LMK itu sendiri memiliki wewenangmemungut atas dasar pemberian kuasa dari para pemegang hak, yaitu para pencipta dan pelaku music. Dengan demikian, wewenang memungut royalti itu sendiri adalah wewenang yang didelegasikan oleh pemegang hak, yaitu pencipta dan pelaku music kepada LMK. Ijin operasional dari Menteri diperlukan dalam rangka pengawasan public (Pemerintah) agar LMK-LMK dalam melakukan pemungutan dan distribusi dilakukan secara accountable, transparent, dan trustworthy.

Berdasarkan hubungan hukum tersebut menjadi sulit dipahami ketika Menteri membuat aturan yang isinya pengaturan pendelegasian kewenangan memungut royalti dari LMKN kepada LMK. ${ }^{16}$ Delegasi wewenang yang mana? Menteri tidak mempunyai hubungan hukum dengan pemilik hak cipta maupun hak terkait. Dengan demikian dapat dipertanyakan delegasi wewenang yang mana yang didelegasikan dari LMKN kepada LMK. Berdasarkan gagasan atau latar belakang pembentukannya, LMKn itu sendiri harusnya dibentuk oleh LMK-LMK dalam rangka penyederhanaan pemungutan royalti dari para pengguna. ${ }^{17}$ Dengan demikian, lebih masuk akal jika delegasi memungut itu diberikan oleh LMK-LMK kepada LMKn atas dasar kekuatan Surat Kuasa dengan hak substitusi.

Pendelegasian wewenang hanya dapat dilakukan atas apa yang menjadi wewenangnya. Dalam sistem hukum berlaku asas nemo plus iuris, yaitu suatu asas yang menyatakan bahwa seseorang tidak dapat mengalihkan hak melebihi apa yang menjadi haknya. ${ }^{18}$ Yang dapat mengalihkan hak menagih royalti hanyalah pemegang hak atas royalti tersebut, yang dalam hal ini adalah para

No.4, (Summer, 1973), halaman 719 - 746. Lihat pula Sulistiowaty Irianto, "Pluralisme Hukum Sebagai Suatu Konsep Dan Pendekatan Teoritis Dalam Perspektif Global" Asosiasi Studi Sosio Legal Indonesia, dalam <https://asslesi.wordpress.com/2011/07/11/pluralisme-hukum-sebagai-suatu-konsep-danpendekatan-teoretis-dalam-perspektif-global/>, diakses pada tanggal 9 Maret 2016.

${ }^{16}$ Lihat Pasal 5 ayat (4) Permenkumham No. 29 Tahun 2014.

${ }^{17}$ Lihat kembali uraian sebelumnya.

${ }^{18}$ Nemo plus juris ad alium transferre potest quam ipse habet $=$ no one can transfer more right to another than he has himself. Lihat Black's Law Dictionary, (St. Paul Minn., West Publishing Co., 1990), hal. 1038. 
pemegang hak, yaitu para pencipta dan pelaku music. Itu sebabnya, UUHC 2014 menegaskan bahwa LMK yang telah mendapatkan ijin operasional dari Menteri, berwenang (diperbolehkan) memungut royalti dari para pengguna music. Haknya berasal dari para pemegang hak dalam bentuk kuasa, sedangkan ijin operasionalnya diberikan oleh Menteri sebagai lembaga public yang memang memiliki otoritas terkait perijinan. Dengan kata lain, ijin adalah memang merupakan kewenangan administrative yang menjadi domain lembaga administrasi seperti Kementerian yang dimaksud. Secara analogi, dapat dipadankan dengan ijin usaha perdagangan yang biasa diterapkan dalam dunia bisnis. Hak pelaku bisnis adalah menjalankan kegiatan usaha. Namun sebelum menjalankan usahanya itu diperlukan ijin usaha.

Menteri adalah pembantu Presiden yang memegang kekuasaan eksekutif menjalankan pemerintahan Negara berdasarkan aturan hukum. Dengan demikian, yang dimiliki oleh Menteri adalah wewenang melaksanakan undangundang, dalam hal ini salah satunya adalah UUHC 2014. Di antara substansi pengaturannya adalah lembagaHak Cipta dan Hak Terkait. Ketentuan ini tidak berarti bahwa Menteri kemudian menjadi lembaga pemegang hak cipta dan hak terkait, atau sekurang-kurangnya Menteri tidak dapat membuat hukum sendiri yang memungkinkan LMKN mendelegasikan wewenang kepada LMK untuk memungut royalti. Menteri adalah lembaga eksekutif yang menjamin pelaksanaan hak para pencipta dan pelaku music untuk dapat diimplementasikan (to administrate) dan ditegakkan (to enforce). Pendelegasian hak cipta dengan pendelegasian hak administratif itu dua hal yang sangat berbeda. Yang dapat didelegasikan oleh Menteri kepada lembaga di bawahnya adalah kewenangan administatif yang menjadi wewenangnya. Sedangkan hak perdata yang dimiliki oleh subjek hukum perdata, yang dalam hal ini para pencipta dan pelaku musik, hanya dapat didelegasikan oleh para pemegang haknya itu sendiri.

Berdasarkan pemahaman tersebut, akan menjadi persoalan hukum yang cukup serius ketika Menteri membuat aturan yang berisi pendelegasian dari LMKN kepada LMK untuk memungut royalti sebelum LMKN itu sendiri mendapatkan delegasi memungut royalti dari para pencipta atau pelaku musik. Justru LMK-LMK itulah yang atas dasar kuasa dari para pencipta dan pelaku music, dan karenanya dapat mendelegasikan hak memungutnya kepada LMKN dalam rangka penyederhanaan pemungutan menjadi "satu pintu", agar pengguna tidak bolak-balik didatangi LMK-LMK yang berbeda-beda yang masing-masing mendapat kuasa dari para pemegang hak. Dengan kata lain, ketentuan yang tercantum dalam Permenkumham No. 29 Tahun 2014Pasal 5 ayat (4) itu merupakan sesuatu yang terbalik dilihat dari doktrin hukum yang dikenal.

\section{Bagaimana Membentuk Lmkn dan Apa Wewenang LMKn}

Dari uraian-uraian di atas sudah dapat disimpulkan bahwa pembentukan LMKn berdasarkan doktrin hukum yang ada dan berdasarkan kebutuhan praktis dalam penyederhanaan poses pemungutan royalti "satu pintu" adalah 
melalui kesepakatan di antara LMK-LMK yang sudah ada. Tentu saja UUHC 2014 harus dilaksanakan secara konsekuen, yaitu bahwa demi keamanan dan kenyamanan pemegang hak yang telah memberi mandat kepada LMK-LMK diperlukan persyaratan administatif dari para LMK agar mampu menjalankan fungsinya sebagai mandataris pencipta dan pelaku music. Pasal 88 ayat (2) mengharuskan dipenuhinya persyaratan tersebut sebelum suatu LMK dapat menjalankan kegiatannya.

Boleh saja Pemerintah membantu memfasilitasi proses pembentukan LMKn yang dimaksud, tetapi tidak harus melakukan sendiri proses pembentukannya melalui Panitya Seleksi. ${ }^{19}$ Apalagi dengan membentuk lembaga yang berbeda esensinya dari LMKn yang dimaksud UUHC 2014, sebagaimana LMKn yang berbentuk Komisi dan beranggotakan Komsioner. Pemberian fasilitas tersebut dilakukan dalam bentuk pembuatan regulasi tentang bagaimana caranya LMK-LMK itu dapat membentuk LMKn, dan bagaimana melindungi kepentingan pihak ketiga, yang dalam hal ini adalah para pengguna music agar tidak terganggu dengan datangnya LMK-LMK yang akan memungut royalti atas nama para pemegang hak.

\section{Memanfaatkan yang Sudah Terjadi}

Dalam pembahasan doktrin hukum, cukup banyak ajaran atau aliran yang membahas tentang hukum itu sendiri. Salah satu yang cukup populer adalah aliran positifisme yang berpandangan bahwa apa yang menjadi hukum adalah semua aturan yang ditetapkan oleh pembentuk hukum yang berwenang. Aliran ini biasanya sangat berpegang teguh pada aturan normatif yang sudah ditetapkan di dalam undang-undang. Para sarjana menyebutnya sebagai legisme.

Di samping aliran legisme ada juga yang melihat hukum dari segi kemanfaatannya. Hukum itu dibuat untuk membawa manfaat bagi orang banyak. Ungkapan yang sangat terkenal adalah apa yang dikemukakan oleh Jeremy Bentham: "the ultimate end of legislation is the greatest happiness of the greatest number" ${ }^{20}$ Aliran ini lebih mementingkan kemanfaatan hukum ketimbang pandangan legisme yang mengukur benar dan salah hanya dari perspektif normatifnya atau dari bunyi undang-undang.

Dalam konteks LMK dan LMKn, boleh saja mengungkapkan kekeliruankekeliruan normative yang terjadi dalam proses pembentukan LMKn, tetapi tidak harus menyesalinya dan kemudian menggugurkan kemanfaatan yang sudah dirasakan ada. Boleh jadi proses pembentukan LMKn secara normative mengandung kekeliruan, tetapi akan lebih bermanfaat jika apa yang sudah terlanjur terjadi itu yang kemudian diperbaiki demi kemanfaatan yang lebih

\footnotetext{
${ }^{19}$ Lihat Pasal 8 ayat (4) Pemenkumham No. 29 Tahun 2014.

${ }^{20}$ Jeremy Bentham, "The Principles of Morals and Legislation", dalam W. Friedmann, Legal Theory, (New York: Columbia University Press, 1967), 313.
} 
besar. Tentu saja perbaikan itu tetap harus mengupayakan pemenuhan terhadap aturan hukum yang ada. Salah satunya, dan yang terpenting adalah mengubah status LMKn yang "setengah" lembaga public ${ }^{21}$ itu menjadi sepenuhnya lembaga swasta.

Paparan di atas telah memberikan gambaran bagaimana sebaiknya LMKn itu diubah menjadi LMKn (dengan huruf kecil) yang sesuai dengan aturan hukum berdasarkan UUHC 2014. Yang perlu dicatat adalah, apa yang sudah dilakukan oleh Pemerintah melalui Permenkumham No. 29 Tahun 2014, khususnya tentang pembentukan LMKn untuk pertama kali berdasarkan Pasal 8 ayat (4) harus dihargai dan tidak boleh disia-siakan. Para Komisioner yang telah bekerja sekian lama harus diberi apresiasi, teutama dalam membangun system pemungutan dan distribusi royalti.

Beberapa perbaikan yang harus dilakukan antara lain:

1. Ketika masa jabatan Komisioner LMKn yang diangkat Menkumham telah berakhir, maka pengisian anggota LMKn berikutnya adalah dengan mengacu pada gagasan utamanya bahwa pembentukan LMKn adalah dalam rangka menyederhanakan system pemungutan "satu pintu", sehingga dengan demikian hal pertama yang harus dilakukan adalah mengisi anggota LMKn dengan mengirimkan utusan-utusan LMK yang sudah mendapatkan ijin operasional.

2. Sebelum itu, struktur LMKn harus terlebih dahulu diubah menjadi LMKn (n huruf kecil), dengan nomenklatur anggotanya tidak lagi menggunakan istilah Komisioner, melainkan "anggota" yang berasal dari LMK-LMK yang sudah mendapatkan ijin operasional dari Menteri. Secara kelembagaan, LMK nasional harus memenuhi syarat UUHC 2014 Pasal 88 ayat (2), dengan catatan bahwa anggotanya dikirim oleh LMK-LMK yang mewakili para pemegang hak melalui pemberian kuasa substitusi dari LMK-LMK kepada LMKn. Boleh saja di samping anggota yang merupakan utusan LMK-LMK ditambah dengan unsur independen, seperti tokoh musik dan akademisi yang memahami industri musik. Menteri kemudian mengesahkan struktur LMKn yang baru, bukan membentuk LMKn tersebut, karena struktur itu dibentuk dan disepakati oleh LMK-LMK yang sudah mendapatkan ijin operasional.

3. Sebelum itu, Menteri menerbitkan peraturan yang menegaskan bahwa LMKn adalah Federasi atau perkumpulan LMK-LMK, ${ }^{22}$ dengan disertai persyaratan pembentukan dan prosedur perijinan. Boleh saja prosedur itu menggunakan ketentuan Permenkumhan 29 tahun 2014 asalkan hal-hal yang tidak sesuai dengan UUHC 2016

09

${ }^{21}$ Mengacu pada Statuta LMKN yang disahkan Menkumham dengan SK No. HKI.2.OT.03.01-

${ }^{22}$ Acuannnya adalah KUHPerdata (pasal 1653 sampai dengan 1665) dan Staatsblad 1870-64. 
direvisi dengan memperhatikan gagasan-gagasan yang sudah dipaparkan di atas.

4. Selanjutnya perlu dilakukan revisi Statuta LMKn, khususnya menyangkut pernyataan dirinya sendiri sebagai lembaga publik yang berwenang membuat aturan publik. ${ }^{23}$ Aturan yang diterbitkan oleh LMKn adalah tetap aturan privat yang mempunyai daya laku atau lingkup laku tertentu, terutama di kalangan industri musik, yang jika meminjam teori Sally Falk Moore, masuk kategori semiautonomous social field. Aturan itu bukan peraturan (regulasi) yang bersifat publik (administrasi negara).

5. Perlu dilakukan revisi Permenkumham No. 29 Tahun 2014, khususnya yang menyebutkan bahwa LMKn dapat memberikan delegasi kewenangan memungut kepada LMK, karena justru LMKLMK itulah yang mendelegasikan kewenangan kepada LMKn untuk memungut royalti dari pengguna melalui pemberian kuasa substitusi. Hanya dengan cara ini tujuan pembentukan sistem "satu pintu" dapat diwujudkan. Jika LMKn mendelegasikan kembali kepada LMK-LMK, maka situasi pra UUHC 2014 akan muncul kembali, di mana para pengguna didatangi banyak LMK.

\section{Penutup}

Beberapa pasal yang telah diungkapkan di atas memang harus diakui masih bersifat multi-tafsir. Pemerintah sebagai pelaksana UUHC perlu lebih hati-hati, cermat, dan arif dalam mengimplementasi ketentuan UUHC, khususnya berkenaan dengan LMK dan LMKn. Alangkah bijaksananya jika proses perbaikan LMKn sudah mulai dilakukan dengan tetap mengacu pada doktrin hukum yang benar. Ada baiknya terlebih dahulu dilakukan pembinaan dan pemberian fasilitas yang memadai kepada semua LMK yang sudah ada untuk dapat memenuhi semua persyaratan yang ditentukan UUHC 2014. Selanjutnya dilakukan pertemuan-pertemuan dengan semua LMK yang ada guna memfasilitasi perbaikan LMKn yang legal dan berkeadilan (fair) pasca berakhirnya masa jabatan Komisioner yang sudah ada.

Dalam proses itu perlu dipikirkan solusi yang terbaik, agar mengurangi potensi konflik yang ditimbulkan akibat dari ketentuan yang multitafsir. Beberapa langkah berikut mungkin perlu dipertimbangkan:

1. Beberapa ketentuan di dalam UUHC yang mengandung potensi multitafsir perlu dijabarkan dalam Peraturan Pemerintah (PP) yang baik. Misalnya: pembentukan LMKn yang belum diatur di dalam UUHC dapat diatur lebih lanjut dalam PP. Salah satu hal yang penting untuk diperhatikan dalam menyusun PP tentang LMKn adalah bahwa tujuan pembentukan LMKn adalah semata-mata untuk menyederhanakan proses penghimpunan royalti dari para

\footnotetext{
${ }^{23}$ Lihat kembali butir C. Statuta LMKN.
} 
pengguna, yang selama ini mungkin dirasakan kurang nyaman oleh para pengguna karena banyaknya LMK yang datang dan masingmasing melakukan pemungutan. Meskipun demikian, pembentukan LMKn tidak boleh melanggar prinsip-prinsip hukum yang ada. Kedudukan LMKn itu hanyalah pemegang kuasa substitusi dari LMK-LMK yang bergabung. Oleh karena itu persyaratan LMKn sebagai organisasi tentu tidak sama dengan LMK karena LMKn justru tidak boleh mendapatkan kuasa langsung dari para pencipta dan pemilik hak terkait. Konsekuensinya, persyaratan untuk perijinan LMKn pun harus dibedakan dengan perijinan untuk LMK, khususnya berkenaan dengan kuasa substitusi.

2. PP tersebut juga harus menjabarkan bahwa LMKn Hak Terkait itu terdiri atas dua jenis, yaitu: (1) LMKn Pelaku/Artis dan (2) LMKN Produser. ${ }^{24}$ Dengan demikian, PP juga harus membuka peluang kepada para Artis untuk membentuk LMK dan LMKntersendiri, dan tidak "harus" bergabung dengan LKMn Produser. Walaupun demikian, masih tetap diperbolehkan bagi para Artis yang tergabung dengan produser untuk bergabung dengan LMKn Produser. PP yang dibentuk harus benar-benar dapat mewadahi kepentingan para artis tersebut karena UUHC sendiri tidak membatasi bahwa hanya ada 1 (satu) LMKn Hak Terkait. Hal ini sejalan dengan UUHC yang mengkategorikan Hak Terkait ke dalam 3 (tiga) hak, yaitu: Performing Rights para artis/pelaku musik, Producer's Right para produser musik, dan (3) Broadcasting Rights lembaga penyiaran.

3. Bagi para pencipta dan artis penyanyi maupun pemusik, hendaknya tidak ragu-ragu untuk bergabung dengan LMK yang sejalan dengan aspirasi mereka. LMK adalah salah satu wadah penting dalam menghimpun royalti yang menjadi haknya pencipta dan artis, khususnya royalti atas penggunaan karya cipta dan karya rekaman mereka oleh pihak lain dalam ranah komersial. Para pencipta dan artis mempunyai kebebasan yang dijamin UUD untuk berserikat dan berkumpul, dalam hal ini bergabung dengan LMK manapun yang dapat mewakili kepentingan mereka atas pengelolaan hak ekonominya.

4. LMK-LMK yang sudah ada hendaknya meningkatkan profesionalitasnya, khususnya menyesuaikan diri dengan perkembangan jaman dan teknologi, serta mengelola hak-hak pencipta dan artis secara professional dan transparan. Hanya LMK yang professional dan akuntabel yang akan dipercaya oleh pencipta dan artis. Bukan jamannya lagi untuk memaksa para pencipta bergabung dengan LMK tertentu semata-mata karena faktor

24 LMKN Lembaga Penyiaran juga dimungkinkan untuk didirikan oleh lembaga-lembaga penyiaran untuk mengelola hak siar dari karya siaran mereka. 
emosional, melainkan LKM harus bersaing untuk menawarkan kinerja yang profesional dan akuntabel, sehingga pencipta dan artis akan dengan suka rela bergabung memberikan kuasa untuk mengelola hak-hak mereka. 


\section{Daftar Pustaka}

Ali, Chidir. Badan Hukum, Bandung: Alumni, 1987.

Friedmann, W. Legal Theory, New York: Columbia University Press. 1967.

Black's Law Dictionary, St. Paul Minn., West Publishing Co., 1990.

Irianto, Sulistiowaty. "Pluralisme Hukum Sebagai Suatu Konsep Dan Pendekatan Teoritis Dalam Perspektif Global”, Asosiasi Studi Sosio Legal Indonesia, dalam <https://asslesi.wordpress.com/2011/07/11/ pluralisme-hukum-sebagai-suatu-konsep-dan-pendekatan-teoretis-dalamperspektif-global/>, diakses pada tanggal 9 Maret 2016.

Kitab Undang-undang Hukum Perdata, terjemahan R. Subekti.

Moore, Sally Falk. "Law and Social Change: The Semi-Autonomous Social Fields as an Appropriate Subject of Study". Law and Society Review, Vol.7 No.4. Summer, 1973.

Peraturan Menteri Hukum dan HAM Republik Indonesia No. 29 Tahun 2014 tentang Tata Cara Permohonan dan Penerbitan Ijin Operasional Serta Evaluasi Lembaga Manajemen Kolektif.

SK Menteri Hukum dan HAM Republik Indonesia No. HKI.2.OT.03.01-09 tentang Statuta Lembaga Manajemen Kolektif (LMKN).

SK Menteri Hukum dan HAM Republik Indonesia No. M.HH-01.01 Tahun 2014 tentang Penetapan Panitia Seleksi Calon Komisioner Lembaga Manajemen Kolektif Nasional Pencipta dan Lembaga Manajemen Kolektif Nasional Hak Terkait.

Undang-Undang Nomor 16 Tahun 2001 tentang Yayasan.

Staatsblad 1870 - 64 tentang Perkumpulan.

WIPO Performances and Phonograms Treaty (adopted in Geneva on December 20, 1996).

$<$ http://humas.dgip.go.id/press-release-keputusan-pansel-pemilihan-

komisioner-lmkn-di-bidang-lagu-danatau-musik/>, diakses pada tanggal 9 Maret 2016.

<https://id.wikipedia.org/wiki/Organisasi_nirlaba>, diakses pada tanggal 9 Maret 2016.

$<$ https://widalcommunity.wordpress.com/artikel/daftar-nama-label-rekamanindie/>, diakses pada tanggal 9 Maret 2016. 